Katarzyna Piwowar-Sulej

\title{
2.2 IT TOOLS TO SUPPORT KNOWLEDGE MANAGEMENT IN THE PERSONNEL RECRUITMENT AND SELECTION PROCESS
}

\begin{abstract}
Summary: The personnel recruitment and selection (R\&S) process has a fundamental value to an organisation. During the process the following information is gathered: the situation on the labour market, the candidates' features, and expectations towards an employer. The collected and properly processed information becomes the base for developing specific knowledge. It is worth mentioning that the use of this knowledge does not refer to the mere employment of a suitable individual, it can also constitute the basis for implementing changes in particular elements of the HR function.

The above suggests that there is a need for conscious and consistent knowledge management in the area of R\&S. It has been accepted that knowledge management includes performing a cycle of actions, such as gaining knowledge, storing knowledge and implementing changes on the basis of that knowledge. Knowledge management should be "accompanied" by the use of IT tools that are becoming increasingly important in the process of collecting and processing data.

Considering the abovementioned facts, it has been agreed that it is worth considering the possibility of using IT tools in the process of managing knowledge - at the stage of R\&S. The scope of their usage has been presented based on the results of empirical research conducted in 2011 among 96 large companies located in Poland.
\end{abstract}

Keywords: recruitment, selection, knowledge management, IT tools

\section{INTRODUCTION}

The personnel function (HR function) is one of the integral functions present in every organisation and refers to the activities related to the employees and their issues; their essential components include: personnel recruitment and selection (R\&S), placement, development, remuneration and promotions (see Gableta, 2003, p.165).

One may argue that the personnel recruitment and selection process has a fundamental value to the organisation. Recruitment is connected with attracting job candidates for the purpose of future selection. Selection is a series of activities aimed at assessing competencies of candidates and choosing, based on predefined criteria, a suitable person for particular vacancy. As the result of $R \& S$ an organisation has adequate human potential. During the process, the following information is gathered: the situation on the labour market, the candidates' features, and expectations towards the employer. Some information is linked to the R\&S process (e.g., the effectiveness of the method used).

The collected and properly processed information becomes the base for developing specific knowledge. It is worth mentioning that the use of the knowledge does not refer to the mere employment of the suitable individual. Additionally, this knowledge can constitute the basis for implementing changes in particular elements of the HR function.

The above suggests that there is a need for a conscious and consistent process of gathering information during the process of R\&S as well as a wider outlook on the potential possibilities of applying this knowledge. The solution is the concept of knowledge management.

The term knowledge management is not unambiguous. In many reference books, there are a large number of knowledge management definitions. According to W. Grudzewski and I. Hejduk, it is contingent upon two factors: high interest in that subject and relatively short period of conducted scientific discourse, which hinder synthetic interpretation of the so far 
achievements (Grudzewski, Hejduk 2005, ww.e-mentor.edu.pl/artykul/index/numer/8/id/115, 08.07.2012).

Generally, the essence of knowledge management comes down to creation of possibility of obtaining the influence on the resources of knowledge in organisation (Rey, Maassen, Gadeib, Bruecher, 1998, p. 30). It has been accepted that knowledge management includes performing a cycle of actions, such as gaining knowledge, storing knowledge and implementing changes on the basis of that knowledge. Knowledge management is a process in which there is certain sequence of actions and specific relations between various kinds of actions.

Knowledge is defined as 'information combined with experience, context, interpretation and reflection' (Davenport, Long, Beers, 1977, p. 1). The definition implies that man is the only subject of developing knowledge, because man is the only resource of the organisation capable of learning, developing potential and conceptual thinking. However, knowledge management should be "accompanied" by the use of IT tools.

In the current economic reality, the 'minute competitiveness' model has become dominant giving economic opportunity only to those companies that are able to analyse the incoming information streams faster and more efficiently (Kozłowski, 2007, p. 46). As it is pointed out by A.K. Koźminski, knowledge-based organisations have to create very specific and sophisticated information environment. Information processes have to be conducted in the environment of the most advanced information technology including both hardware and software. Beyond such environment, the knowledge cannot be the most productive resource of an organisation (Koźmiński 2008, p. 15).

IT tools are becoming increasingly important in the process of collecting and processing data. The main benefit resulting from applying such tools is shortening the R\&S time through facilitating the communication process with the candidate and the workflow among all the individuals involved in the process. Employees responsible for software development in a company providing, amongst others, systems for HR departments claim that these applications should now be used to support the HR policy, with a particular focus on R\&S (http://gospodarka.gazeta.pl/gospodarka/1,52741,4185707.html, 19.10.2011).

Considering these, it has been agreed that it is worth considering the possibility of using the IT tools in the process of knowledge management - at the level of personnel recruitment and selection ${ }^{7}$. These tools have been related to particular stages of the knowledge management cycle. The scope of their usage has been presented based on the findings of empirical research conducted in 2011 among 96 large companies located in Poland. The research used the quota selection according to industry ${ }^{8}$. They were performed within the 'Internship as the Scientist's Success' project, financed by the European Social Fund. The respondents were HR employees actively involved in the personnel recruitment and selection process.

Results of previous own research conducted in 2009 are also used in the article. There were used the telephone interviews with HR specialists, working in 100 medium and largesized, randomly selected companies located in Poland, operating in production, financial and IT sectors. The research problem was identification of the scope of application and indication of the most popular psychometric tools for selection of job candidates.

\footnotetext{
${ }^{7}$ It refers to commercial tools adjusted to the needs of a particular enterprise. These IT solutions can be delivered by a software development company or developed internally. The subject therefore excludes functionalities offered by some job portals.

${ }^{8}$ Quota selection was based on the proportions featured in the report referring to a separate study, conducted by PKPP Lewiatan in cooperation with Deloitte (http://www.muratorplus.pl/biznes/raporty-i-prognozy/kondycjaduzych-firm-w-polsce-w-czasach-kryzysu_64588.html, 19.10.2011).
} 


\section{KNOWLEDGE MANAGEMENT IN R\&S PROCESS}

Before the idea of knowledge management in relation to $R \& S$ is presented, it is worth to discuss shortly the components of R\&S process (see Fig. 1).

Figure 1: Process of personnel recruitment and selection

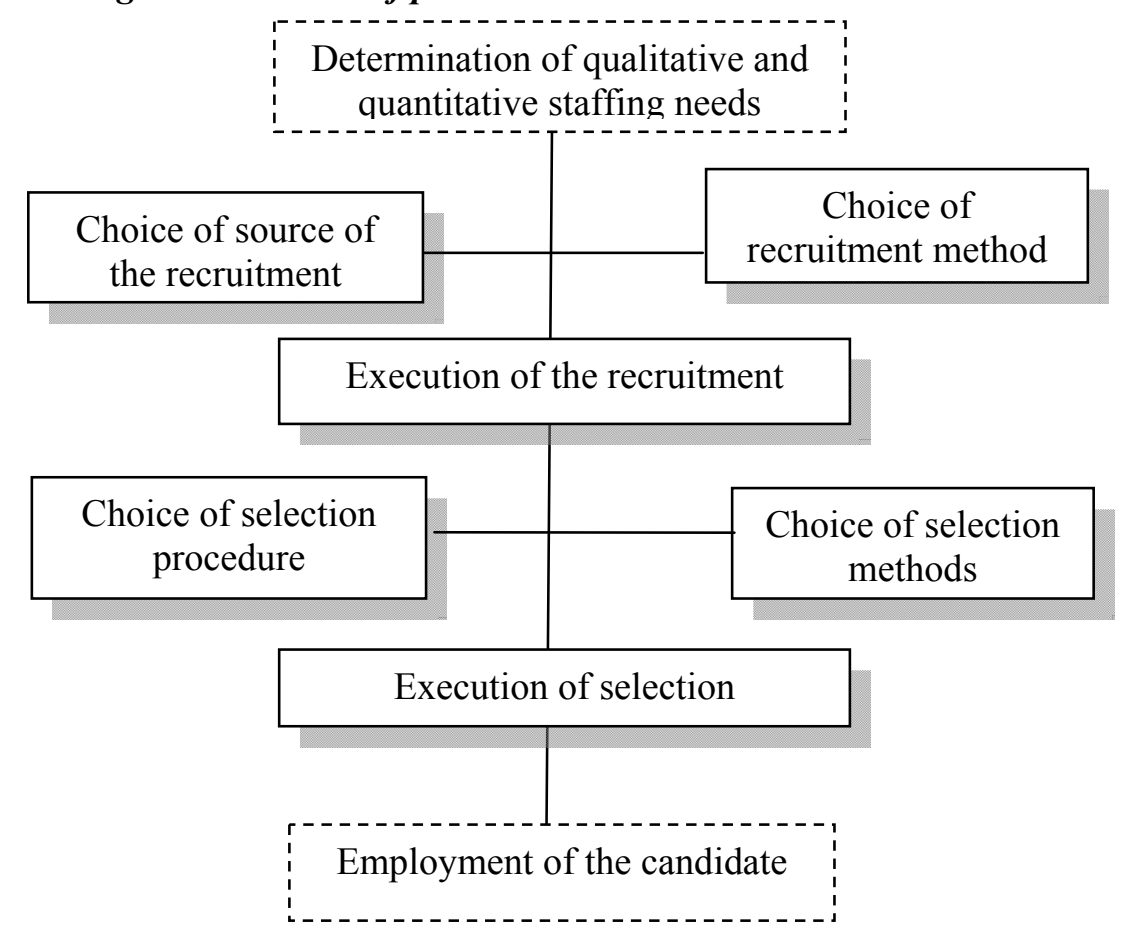

Source: own work on the basis of (Marketing kadrowy; 1997, p. 57)

Actions presented in above figure must be preceded by identification as regards the number of vacancies and by determination of qualitative requirements for job applicants. The so-called desired profile of job candidate is created.

Before the announcement on the existing vacancy is made, there must be decision made, concerning the selection of the source of the recruitment. There are the following sources discriminated: internal (internal labour market) and external (external labour market). Both of mentioned sources have some advantages as well as the disadvantages. (For more, see Suchar, 2005 , p. 29). At the recruitment stage, it is essential to make decision concerning not only the source but also the method. The method is a manner in which the candidates learn about the offered job position.

To examine if a particular candidate meets the criteria included in previously developed profile of requirements, the stages of selection must be adequately designed using those techniques, which enable the best possible assessment of job candidate traits. R\&S process should result in employment of the job candidate with traits which are the most convergent with previously set requirements.

Effective execution of $R \& S$ process must be accompanied by the use of specialist knowledge in the field of instruments used in HR area (R\&S methods and techniques) and the use of knowledge of the labour market and the job applicants. In addition, the significant role is played by the knowledge of creation of employer's image that means creation of relations between the employer and present or future employee.

Only the knowledge, which is useful in operation, is important for an organisation. To make it happen this way, the specific knowledge (regardless of its content) should concern two matters: causalities existing within the organisation and in relations between the 
organisation and its environment (Argirys, 1993, p. 3; Dixon, 2000, p. 11 cited by Godziszewski, 2006, p. 117). That condition is met by the categories of knowledge presented in the above paragraph.

As it was indicated in the introduction, these are not the professional competencies of HR specialists, which is the subject of interest in this paper, but it is the knowledge from the labour market. Then, with such assumption, what is the meaning of knowledge management in $\mathrm{R} \& \mathrm{~S}$ process?

As shown in the introduction to this study, it is assumed that knowledge management is connected to completing the cycle presented in Fig. 2. The stages of knowledge management, which are contained in the figure, can also be related to the different kinds of knowledge occurring in a company. Generally, knowledge management should be considered by paying attention to:

- the functioning of the whole organisation,

- the functioning of the particular organisational units,

- the cross-organisational processes, i.e. through the different organisational units.

Therefore it should be emphasized that knowledge management at the R\&S level should be a part of the overall system of knowledge management in a company.

Figure 2. The cycle of knowledge management in the personnel recruitment and selection process and the results of completing this cycle

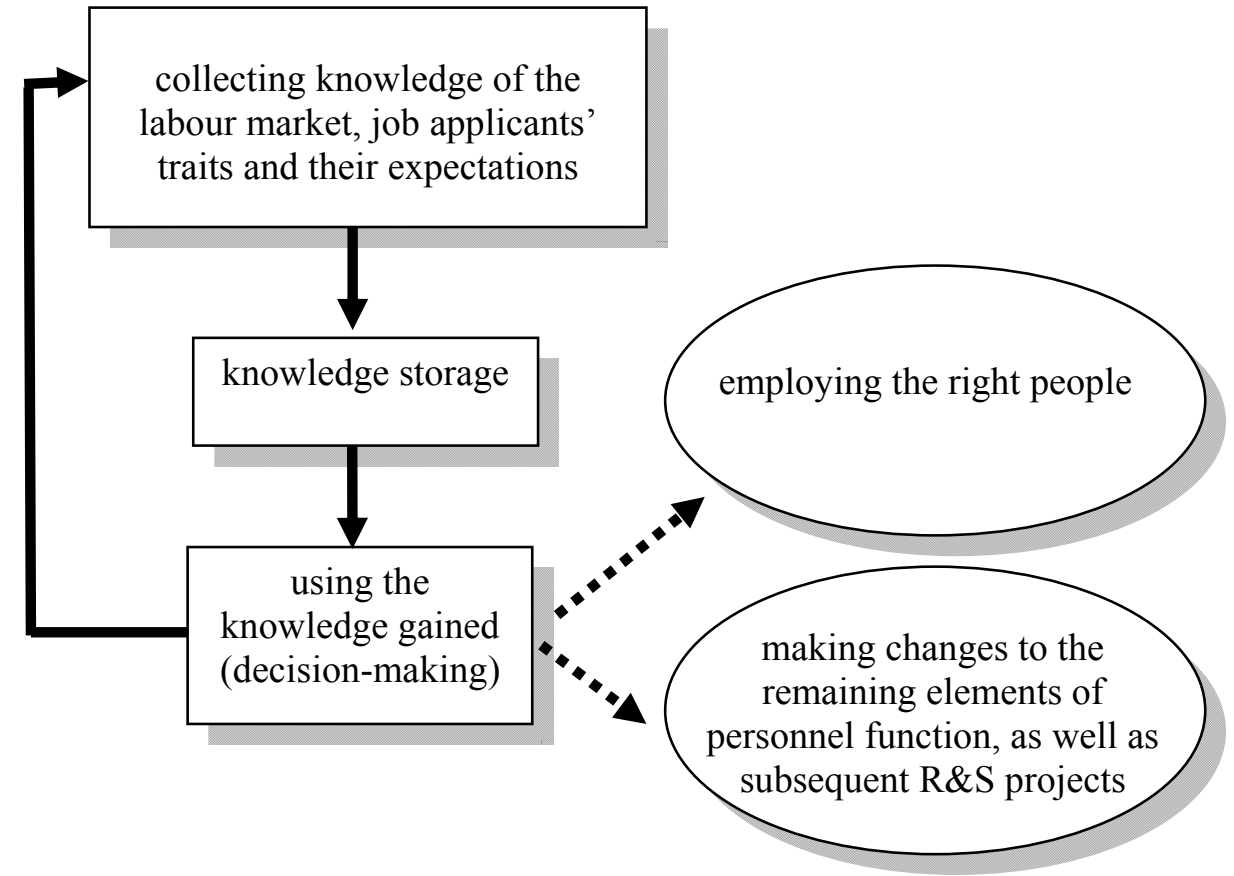

Source: own work

Managers of the enterprises may choose one of the two strategies of knowledge management: codification strategy (technology-oriented) or personalisation strategy (humanoriented) (for more, see Błaszczuk, Brdulak, Guzik, Pawlaczuk, 2003, pp. 26-27). Those aforementioned types of the strategy are directly connected with the increase of the particular types of the knowledge: the first type - with the increase of formal (explicit) knowledge, the second type - with the increase of tacit knowledge. The first one is presented in the form of procedures, records or numerical presentations, as a result of information processing. The second one is the resource constructed upon the basis of experience, skills and intuition of the employees of the enterprise. The main advantage from using the codification strategy is the economy of knowledge reuse (see Fic, 2008, p. 25). In knowledge management process, it is 
justified to combine elements of the aforementioned strategies because it leads to the increase of both types of the knowledge used in company operation.

According to the definition proposed by the Institute for Production System and Design Technologies in Berlin, knowledge management describes the methods, instruments and tools which in a holistic approach contribute to the course of the main processes with a part of the knowledge (more see Mikuła, 2001, p. 59). These methods or tools can be generally divided into those which:

a. allow the processes contained in the cycle of knowledge management to be automated,

b. fall into the "human resources management" category, effecting a change to the personnel's attitude towards knowledge.

Information technologies belong to the first group mentioned above.

\section{THE POSSIBILITY OF USING THE IT TOOLS IN ANALYSED AREA}

When considering the general reasons of using IT tools in the process of personnel recruitment and selection, there must be mentioned the benefits that may be achieved by the business entity through those tools. Those benefits undoubtedly include (Piwowar-Sulej, 2012, p. 550):

- increase of the operation speed and thus, shortening of the time necessary for execution of R\&S process also by improvement of communication with a candidate and the workflow between persons involved in the process,

- elimination or decrease of number of mistakes made by personnel specialists in the analysed process,

- ease of generation of reports on the status of personnel selection projects,

- decrease of costs of R\&S by automation of the actions which would have to be performed by the additional employees

- coping with the fluctuation of the number of recruitment projects.

The aforementioned arguments supporting the use of information technology in personnel recruitment and selection are quite ,hard”. However, it is worth to look at the IT tools not only from the employer's point of view. Also the expectations of present and potential employees have to be taken into consideration.

IT tools facilitate making everyday operations for the employers in HR departments. Moreover, the systems of group work also make the execution of $R \& S$ easier to the other internal parties involved - i.e. to line managers. Thus, IT tools „fall in line" with the idea of the so-called high performance work places (for more, see. Wojciechowska, 2008, pp. 66-68). The employee satisfied with the equipment of his work post will probably tell his family and acquaintances about that, causing dissemination of positive information concerning the employer.

Also generational changes are worth to be taken into consideration. Representatives of the so-called generation $\mathrm{Y}$ have entered the labour market for several years. They show the proficiency in the use of modern technologies and thus, higher expectations towards the employees in that area. For example, from the experience of the paper's author results that they willingly offer to conduct the first job interview via Skype.

The employees should be aware of the foregoing to acquire persons with high potential from the external labour market and to win the involvement of the present employees, influencing this way the evaluation of the company as the work place. Therefore, the use of IT tools helps creating the image of an attractive, modern employer and thus it increases the probability of employing the appropriate person (for more, see Piwowar-Sulej, PietrońPyszczek, 2011, pp. 79-91). 
Coming back to the issues of knowledge management, it has to be stated that in the reference books there is a large number of classifications of IT tools. Two classifications are presented below, while none of them cannot be regarded as the complete one.

According to Jashapara the most popular IT tools making up the global systems of knowledge management are (Jashapara, 2006, p. 370):

- document management systems - making information available to the right people at the right time,

- decision-making support systems, which take place through data collecting and analyzing,

- team support systems,

- managerial information systems - addressed to top managers,

- workflow management systems,

- customer relationship management systems - helping expand knowledge of the customers' individual preferences.

In other view, the aforementioned tools are grouped in three areas. They are (Bernard, 2006 cited by: Rydz 208, p. 338):

- knowledge repositories,

- export directories,

- collaborative tools.

The first group includes document management systems and databases as well as search and retrieval. Experts directories are specific telephone books containing the information about competency profiles of individual employees. Collaborative tools are team support systems, e-mail, discussion lists and instant messengers.

It is worth to be stressed here that there are various offers in the market, which promise the implementation of knowledge management system by purchasing and installation of the acquired software. However, no IT system is able to manage the knowledge independently. Moreover, the purchase of one of the aforementioned IT solutions does not per se mean that the company has implemented the idea of knowledge management system. It is also important that the same IT tool may be used differently in two different organisations - supporting the knowledge management more or less.

Table 1 shows IT tools related to the particular stages of knowledge management in R\&S.

Table 1: The IT tools supporting a completion of the knowledge management cycle as part of personnel recruitment and selection

\begin{tabular}{|l|l|}
\hline \multicolumn{1}{|c|}{$\begin{array}{c}\text { The stage of knowledge } \\
\text { management }\end{array}$} & \multicolumn{1}{c|}{ The IT tools supporting a completion of the particular stage } \\
\hline knowledge collection & $\begin{array}{l}\text { corporate recruitment websites containing not only job offers } \\
\text { but also application forms, }\end{array}$ \\
& $\begin{array}{l}\text { - catalogues (databases) of application documents, } \\
\text { on-line tests (in knowledge, skills, job predispositions) used in } \\
\text { the selection process, }\end{array}$ \\
\hline knowledge storage & $\begin{array}{l}\text { database applications (cataloguing application documents), } \\
\text { systems supporting team work in recruitment projects, }\end{array}$ \\
\hline knowledge use & $\begin{array}{l}\text { pre-selection tools for gathered applications, } \\
\text { a tool creating an applicants' ranking at the end of the } \\
\text { recruitment and selection process. }\end{array}$ \\
\hline
\end{tabular}

Source: own work

Emphasis is put mainly on the primary goal of management, namely on employing an applicant with adequate capacity. As pointed out in Fig. 2, there are also other possibilities to exploit knowledge such as making changes to the remaining elements of HR function (on the 
basis of the expectations postulated by applicants) and modifying the process of personnel recruitment and selection itself (on the basis of previous learning experiences).

In this way, it should be found that knowledge importation is favourably enhanced by employing a tool such as an application form. It forces an applicant to provide information in which an employer is interested (e.g. education, work experience, expectations about work and salary conditions).

The basic requirement for applicants of different positions is possessing defined knowledge and occupational skills. The indicated competence can be checked using, amongst others, IT systems. These can be test-dedicated tools or e-learning software, which - so to speak "as the opportunity arises" - allows checking the level of competence in a particular thematic field. IT tools can also help determine the level of intelligence, personality type, and occupational predispositions of an applicant. Many so-called psychometric tools for selecting job applicants have an electronic form (more see Piwowar-Sulej, Grajewski, 2010, pp. 92100).

Using information technologies generally facilitates knowledge codification and storage. Codification allows the significant reduction of knowledge distortions occurring in the traditional procedure of information sharing (through interpersonal communication). Every authorized employee can obtain from the knowledge base as much knowledge as they need in so far as their permissions allows them. It is important for all interested parties to have access to the knowledge they need. That is why systems facilitating teamwork within personnel $\mathrm{R} \& \mathrm{~S}$ projects are significant tools. Depending on the requirements for a given position, for which an applicant is searched, the HR personnel, line managers (management at different levels), and board will take part in the selection process.

Using knowledge means making the right decision. The decision-making process can be sped up with tools serving to preselect the filed applications or creating rankings of potential employees. Thanks to the use of the application form on the corporate website, shown above, applicants are forced to provide answers to the most important selection questions. Next, the applications meeting the basic job requirements can be selected in an easy way. Systems supporting verification of the applications' documents (CVs, cover letters) by searching databases with the applicants have also appeared on the information technologies market, supporting the human resources function. Thanks to these, application documents, which prove that an applicant does not meet the basic selection requirements, are quickly rejected from the company's own database.

The figure presented above should be treated as a proposal that should be updated along with development in the field of information technology. There is a necessity of permanent analysis of information technology market in terms of implementation of increasingly modern, comprehensive and concrete solutions. It is worth to be stressed here that the tools presented in the Table 1 may be separate applications or functions offered as a part of one global IT system. There are systems, which combine the functions presented above within themselves. Applicant tracking system (ATS) enables the complex electronic management of the needs connected with personnel selection. ATS systems are very similar to CRM systems (customer relationship management systems) but they are designed to manage the relationship with job candidates. Advanced ATS systems enable even the full automation of the recruitment process.

The needs expressed by the employees of HR departments are also significant. In empirical research - shown in the next part of the article - emphasis was then put on both the popularity of using certain information solutions and the reasons behind it. 


\section{THE SCOPE OF USING IT TOOLS IN THE PERSONNEL RECRUITMENT AND SELECTION PROCESS - THE RESULTS OF EMPIRICAL RESEARCH}

When dealing with the issues of the use of IT technology in the process of job candidates selection, the significance of the Internet cannot be ignored. Portals with job offers are particularly popular. Information presented in such websites is very attractive for people looking for jobs because of a considerable amount of advice, remarks and tips.

The increasing accessibility of on-line resources cause that enterprises design their own home pages. At the beginning, such websites were strictly informative and provided merely the activity profile of an enterprise or sale offer. In the course time, his kind of advertising drew attention of HR departments. As a result, website designers included bookmarks with job offers and information about job opportunities in a given company in the structure of home pages (Wrzalik, Sokołowski, 2009, pp. 447-456 cited by: Niedbał, Wrzalik, 2011, p. 239).

Studies of the reference books allow stating that the employers more and more frequently use the company website for searching for necessary employees. Such conclusions come not least from the latest report „Resources and Talent Planning” prepared by The Chartered Institute of Personnel and Development. As many as 59\% of 626 companies found developing of their own websites - particularly in the part dedicated for career opportunities - being the best way to attract the job candidates (Jak efektywnie..., 2011, p. 3).

As it results from the analyses of the content of the websites of 100 largest companies in Poland - „Pracodawcy online” („Employers online”) - 70\% of examined companies place at their websites information about the career within the company organisation and $46 \%$ of them publish current job offers. Bookmarks for people interested in apprenticeship and internship programmes were placed at $32 \%$ of corporate websites of the analysed companies. The largest companies provide multistage systems of searching for offers and the companies belonging to global concerns usually have the international base of offers, accessible in English. Companies try to enable the potential employees to make the job application in the fastest and easiest possible way that means via Internet (Trojan-Stelmach; 2008, p. 42).

Taking the foregoing into consideration, in the procedure of own research in 2011 the following research hypotheses were formulated:

1) Due to the increasing popularity of recruitment portals, in large companies the IT tools enabling the job offer placing at company website are the most frequently used.

2) Employees responsible for personnel selection feel the need to use IT tools in personnel selection process. The scope of usage of those tools, however, is determined mainly by the cost of purchase of the software in relation to the potential benefits.

Hypothesis No.1 was verified positively. $79 \%$ of the examined companies are equipped with tools for placing the job offers at the company website. What is the situation regarding application forms and other tools characterized previously? The synthetic results of research on the scope of using these IT tools are summarized in Table 2.

As regards the form in which the base of candidates for the needs of particular recruitment is made, only $21 \%$ of companies have IT system organising application documents. In other companies, the relevant files are saved to the hard drives or they are left in electronic mail folders. In one of the companies, the base was created in MS Excel. It is surprising that in two companies the documents are maintained in paper form.

The research proved that by far the largest reserves (shortages) in the scope of using IT tools lie in the selection process. It mainly concerns electronic tools serving to conduct job interviews and to verify knowledge, skills and occupational predispositions of the applicants.

It must be stated that not many - only 8 companies - use e-learning systems in which the knowledge tests are included. It results probably from low popularity of the use of e-learning 
in Poland. As it was presented in 2007 in the document „National Strategic Reference Framework" issued by The Ministry of Regional Development, only 3\% of all Polish companies use e-learning, which is a low rate against the background of other European Union countries (http://www.edustat.com.pl/pub.html?nr=15, 31.03.2011).

Table 2. The popularity of using company IT tools serving to recruit and select personnel

\begin{tabular}{|l|c|}
\hline \multicolumn{1}{|c|}{ The scope of using an IT tool } & $\begin{array}{c}\text { The popularity of using (\% of the } \\
\text { companies using a given tool) }\end{array}$ \\
\hline corporate recruitment websites & $79 \%$ \\
\hline $\begin{array}{l}\text { cataloguing (the databases) and preselecting the applications } \\
\text { filed via the application form }\end{array}$ & $21 \%$ \\
\hline $\begin{array}{l}\text { team work in recruitment projects (human resources } \\
\text { department and other interested parties) }\end{array}$ & $35 \%$ \\
\hline e-learning tools to carry out knowledge and skill tests & $8 \%$ \\
\hline $\begin{array}{l}\text { knowledge and skill tests exclusively dedicated to the } \\
\text { personnel selection process }\end{array}$ & $18 \%$ \\
\hline personality, intelligence, occupational predispositions tests & $13 \%$ \\
\hline online interviews with the applicants & $7 \%$ \\
\hline
\end{tabular}

Source: own work on the basis of the results of research done

It is assumed that the use of personality, intelligence or professional predisposition tests significantly increases the probability of correct selection of job candidate. The effectiveness of those tests is from $20 \%$ to $50 \%$ better comparing to random selection, unstructured method, or graphologic method (Goffin and Helmes; 2000, pp. 421-454; Robertson and Makin; 2007, pp. 31-32,34-36). However, the results of studies conducted in 2009 show that only 58 of 100 companies use those tools, including the fact that 22 of 100 companies use them in electronic form (see Table 3, for more, see Piwowar-Sulej, Grajewski, 2010, pp. 92-100).

Table 3. Popularity of electronic psychometric tools for diagnose of the potential of job candidates

\begin{tabular}{|l|l|c|}
\hline \multicolumn{1}{|c|}{ Tool name/author/publisher } & Distributor in Poland & $\begin{array}{c}\text { Popularity (\% of the } \\
\text { examined companies which } \\
\text { use the tool) }\end{array}$ \\
\hline $\begin{array}{l}\text { INSIGHTS DISCOVERY } \\
\text { Publisher: Insights Discovery Ltd }\end{array}$ & Insights Polska LTD & $3 \%$ \\
\hline $\begin{array}{l}\text { SUCCESS INSIGHTS, W. M. Marston } \\
\text { Publisher: TTL Inc Success Insights } \\
\text { International Inc. }\end{array}$ & GoldenMark & $3 \%$ \\
\hline $\begin{array}{l}\text { EXTENDED DISC } \\
\text { Publisher: Extended Disc International }\end{array}$ & $\begin{array}{l}\text { Extender DISC } \\
\text { Polska LTD }\end{array}$ & $6 \%$ \\
\hline $\begin{array}{l}\text { PAPI, Proselect } \\
\text { Publisher: Cubicks / Alta }\end{array}$ & ALTA LTD & $4 \%$ \\
\hline $\begin{array}{l}\text { APOs } \\
\text { Publisher: SLG Thomas }\end{array}$ & SLG THOMAS INTER- \\
\hline $\begin{array}{l}\text { M5Q, MBS, DiSC } \\
\text { Publisher: Meurs }\end{array}$ & NGATONAL POLAND LTD & $2 \%$ \\
\hline $\begin{array}{l}\text { MGIB, OPQ32, MQ, } \\
\text { Publisher: SHL Ltd. }\end{array}$ & SHL Polska LTD & $2 \%$ \\
\hline & total & $2 \%$ \\
\hline
\end{tabular}

Source: own work on the basis of (Piwowar-Sulej, Grajewski, 2010, pp. 95-96) 
Significantly, the majority of the companies researched launches over 20 personnel selection projects every year. It then seems that the IT tools - according to the reasons for using thereof presented above - would significantly facilitate the process of gathering, storing, and using knowledge of the applicants and thereby contribute to employing the right persons.

As shown earlier, the respondents were also asked the reason for not using information technology. The answers to this question are provided in table 4.

Table 4. The most frequent reasons for not using company IT tools serving personnel recruitment and selection

\begin{tabular}{|l|c|c|}
\hline \multicolumn{1}{|c|}{ The scope of using an IT tool } & $\begin{array}{c}\text { The most } \\
\text { frequent reason }\end{array}$ & $\begin{array}{c}\text { Percentage of the } \\
\text { respondents } \\
\text { providing } \boldsymbol{a} \\
\text { reason }\end{array}$ \\
\hline \hline corporate recruitment websites & no need & $21 \%$ \\
\hline cataloguing (the databases) and preselecting the applications & no need & $38 \%$ \\
\hline $\begin{array}{l}\text { team work in recruitment projects (human resources } \\
\text { department and other interested parties) }\end{array}$ & no need & $46 \%$ \\
\hline e-learning tools to carry out knowledge and skill tests & no need & $68 \%$ \\
\hline $\begin{array}{l}\text { knowledge and skill tests exclusively dedicated to the } \\
\text { personnel selection process }\end{array}$ & no need & $46 \%$ \\
\hline personality, intelligence, occupational predispositions tests & no need & $46 \%$ \\
\hline online interviews with the applicants & no need & $67 \%$ \\
\hline
\end{tabular}

Source: own work on the basis of the results of research done

Research indicates that the main reason for not using IT tools in every scope is not the lack of appropriate offers or the expense of purchasing software, but not feeling the need to use these tools. Thus, the hypothesis No. 2 was verified negatively.

The presented approach to the selection of applicants for a job corresponds to the results of research conducted by Sokołowski, concerning the use of information technology in the process of diagnosing the predispositions of decision-making managers. $22 \%$ of the respondents - the HR experts - found the identification of the shown managerial competence insignificant (more see Sokołowski, 2011, pp. 31-34).

What is the cause of no need for the use of IT tools felt by HR specialists? A certain answer may come from the analysis of types of the personality connected with rejection of an idea (solution, proposal, etc.). In Table 5, there are presented the possible personality types with the consideration of the level of knowledge in the field which was the base of making „no need" decision.

In case of opportunists, the lack of knowledge and imagination concerning the using of IT tools does not allow acceptance of the rational arguments supporting the realization of innovative project. That is why they search for "no" arguments. Dogmatists simulate having the knowledge with the awareness of their own incompetence. The change may be the attempt on their rights and finally, on their position. There is arising a tendency in them to collect information about the negative consequences of implementation of IT systems. Finally, the agnostics have the knowledge but they cannot apply it to the operational conditions of the company they work in. In such persons' point of view, informatics and new technologies are for the large, wise and rich ones. 
Table 5. Personality types connected with the attitude of rejection of IT tools with the consideration of the level of knowledge in IT tools

\begin{tabular}{|c|c|}
\hline Knowledge & Personality type \\
\hline none & opportunist \\
\hline rudiments & dogmatist \\
\hline owned & agnostic \\
\hline
\end{tabular}

Source: own work on the basis of (Fic, 2008, p. 117)

Change of the „no need" attitude certainly requires the deepened diagnosis of the cases of particular organisation and people. However, some kind of receipt may be suggested. It consists in taking the following actions (cf. Fic, 2008, pp. 120-121):

- systematic training of the personnel in the idea of knowledge management and the meaning of new technologies,

- change of organisational culture profile towards such values as knowledge and information,

- reorientation of the role of HR department towards HR business partner.

The first of the postulates is the easiest to be implemented. Actions indicated here may become a foundation of the subsequent changes. HR business partner must have competences both in personal and business area. Only then it may provide HR solutions (also the IT tools) in response to the strategic needs of the organisation.

People managing the companies which do not have the advanced tools for personnel recruitment and selection, but also those in which, according to the results of the research, adequate IT tools have been implemented, are worth to be made sensitive to the fact of the presence of technological barriers in knowledge management. A. Riege points out that the most significant of those barriers are manifested by (for more, see Riege, 2005, pp.23-29):

- lack of integration between system and task execution processes,

- lack of communication about the benefits,

- lack of consideration of individual user needs,

- lack of technical support and lack of trainings in system operation,

- unrealistic expectations towards the employees concerning the knowledge of a particular technology.

\section{CONCLUSIONS}

A modern company to be fully competitive should fulfil the following conditions:

- possess adequate knowledge,

- be able to use this knowledge appropriately.

It concerns any kind of knowledge occurring within a company - significant for making the right business decisions.

The popularity is being won by the idea of knowledge management which promotes the conscious and systematic taking of actions leading to the increase of the knowledge within the organisation and its adequate use. In this article, the significance of knowledge management at the level of personnel recruitment and selection was stressed. The indicated elements of the HR function are fundamentally important for a company. As a result of these, it has adequate human resources at its disposal.

IT tools, which utilize information resources as a factor of support for management processes, are becoming an essential capital in management. Application of information technology in contemporary organisations is a natural process. IT tools can contribute to an increase in effectiveness of completing the knowledge management cycle at the R\&S level 
through facilitating and speeding up the process of collecting information on the applicants' qualifications required for a job as well as their expectations towards employers and preselecting the applications.

In this article, the author's own classification of these tools was introduced with reference to the levels of the knowledge management cycle taking the main goal of this management employing the right applicants - into consideration. The results of empirical research concerning the use of particular IT tools were also presented.

Research indicates decreased popularity of IT tools supporting job applicant selection. The fact that the main reason for not using IT tools within the different scopes of the personnel selection is not feeling the need to use modern technologies by the employers of the HR departments is shocking. In the article there are presented the potential causes of "no need" attitude and possibilities of its change.

To sum up, it should be stressed one more time that the significance and complexity of knowledge management results from the interdisciplinary nature of this idea. Not only does success in this matter depend on the employed information solutions but also on the people who use them. It is worth to point out again that the knowledge management should cover the entire organisation, not only its selected functions, such as HR function or its component $\mathrm{R} \& \mathrm{~S}$ process.

\section{REFERENCES}

1. Argirys Ch., 1993, Knowledge for Action. A Guide for Overcoming Barriers in Organizational Change, Jossey-Bass Publishers, San Francisco.

2. Bernard J.-G., 2006, A Typology of Knowledge Management System Use by Teams, Proceedings of the 39th Hawaii International Conference on Social Science.

3. Błaszczuk A., Brdulak J., Guzik M., Pawlaczuk A., 2003, Zarządzanie wiedzą w polskich przedsiębiorstwach. AGH, Warszawa.

4. Davenport T.H., Long D.W.D., Beers M.C., 1997, Building successful Knowledge Management Projects, Working Paper. Ernst \& Young Center for Business Innovation.

5. Dixon N.M., 2000, Common Knowledge. How Companies Thrive by Sharing What They Know, Harvard Business School Press, Boston.

6. Fic M., 2008, Zarządzanie wiedzą - mnogość teorii i niedostatek praktyki, in: Wiedza. Innowacyjność. Zmiana, ed. J. Stankiewicz, Wyd. Uniwersytetu Zielonogórskiego, Zielona Góra.

7. Gableta M., 2003, Człowiek i praca w zmieniającym się przedsiębiorstwie. AE, Wrocław.

8. Godziszewski B., 2006, Istota i główne problemy zarządzania wiedzą w przedsiębiorstwach, in: Zarządzanie wiedzą jako kluczowy czynnik międzynarodowej konkurencyjności przedsiębiorstwa, ed. M.J. Stankiewicz, Dom Organizatora, Toruń.

9. Goffin, R. D., Helmes E., 2000, Problems and solutions in Human Assessment, Kluwer Academic.

10. Grudzewski W.M., Hejduk I., 2005, Zarządzanie wiedzą w organizacjach, „E-mentor” no 1 (8), ww.e-mentor.edu.pl/artykul/index/numer/8/id/115, 08.07.2012

11. Jak efektywnie przyciągać kandydatów do pracy?, HRspot, Biuletyn zespołu ds. podatków pracowniczych i doradztwa personalnego, PwC Polska, lipiec 2011, no 41.

12. Jashapara A., 2006, Knowledge Management, PWE, Warsaw.

13. Kozłowski K., 2007, Gigabajty personalne, „Personel”, no 10.

14. Koźminski A.K., 2008, Wstęp, in: Zarządzanie wiedzą, ed. D. Jemielniak, A.K. Koźminski, Wydawnictwa Akademickie i Profesjonalne, Warszawa.

15. Marketing kadrowy, 1997, ed. L. Krysztofiak, Wyd. CH Beck, Warszawa. 
16. Mikuła B., 2001, W kierunku organizacji inteligentnych, Antykwa, Kraków.

17. Niedbał R., Wrzalik A., 2011, Information Solutions in the Area of E-recruitment-Selected Aspects, in: IT Tools in Management and Educations. Selected Problems, ed. L. Kiełtyka, Serie Monographs, No 213, Czestochowa University of Technology, Częstochowa.

18. Piwowar-Sulej K., Grajewski B., 2010, Psychometryczne narzędzia selekcji kandydatów do pracy, in: Nowoczesne kierunki w zarządzaniu przedsiębiorstwem, ed.. J. Lichtarski, Prace Naukowe UE we Wrocławiu no 89, Wrocław.

19. Piwowar-Sulej K., Pietroń-Pyszczek A., 2011, Employer branding using modern technologies, in: IT Tools in Knowledge Management in Organisations, ed. L. Kiełtyka, Serie Monographs, No 211, Czestochowa University of Technology, Częstochowa.

20. Piwowar-Sulej K., 2012, Narzędzia IT w procesie doboru personelu - przesłanki oraz zakres stosowania, „Management” no 1, University of Zielona Góra.

21. Rey M., Maassen A., Gadeib A., Bruecher H., 1998, Stufenmodell zur Einfuerung von Wissenmanagement, „IM Information Management“, no 13(1).

22. Riege A., 2005, Three-dozen knowledge-sharing barriers manager must consider, „Journal of Knowledge Management" vol. 9, no. 3.

23. Robertson I. T. Makin P. J., 2007, Metody selekcji i ich wykorzystanie, in: Dobór Personelu, ed. T. Witkowski, Biblioteka Moderatora Taszów.

24. Rydz A., 2008, Systemy informatyczne wspomagające zarządzanie wiedzą, in: Zarządzanie wiedzą, ed. D. Jemielniak, A.K. Koźminski, Wydawnictwa Akademickie i Profesjonalne, Warszawa.

25. Sokołowski A., 2011, Struktura funkcjonalna oraz wirtualne środowisko systemu wspomagającego proces identyfikacji predyspozycji decyzyjnych menedżerów, in: Narzędzia informatyczne w gospodarce. Electronic and decision-making support systems, Seria Monografie nr 210, ed. L. Kiełtyka, Politechnika Częstochowska, Częstochowa.

26. Suchar M., 2005, Rekrutacja i selekcja personelu. Wyd. C. H. Beck, Warszawa.

27. Trojan-Stelmach M., 2008, Wyklikaj firmie pracownika, „Marketing w Praktyce”, No 4.

28. Wojciechowska A., 2008, Innowacyjne środowisko pracy, „Personel Plus”, no 7.

29. Wrzalik A., Sokołowski A., 2009, E-rekrutacja w Polsce - wybrane aspekty, in: Multimedia w biznesie i zarządzaniu, ed. L. Kiełtyka, Wydawnictwo Difin, Warszawa.

30. http://www.edustat.com.pl/pub.html?nr=15, 31.03.2011

31. http://gospodarka.gazeta.pl/gospodarka/1,52741,4185707.html, 19.10.2011

32. http://www.muratorplus.pl/biznes/raporty-i-prognozy/kondycja-duzych-firm-w-polsce-wczasach-kryzysu_64588.html, 19.10.2011 